\title{
Assess the Effect of Micronutrients and Bio-regulators on Growth, Flowering, Fruiting and Yield of Guava (Psidium guajava) cv. Allahabad Safeda
}

\author{
Jotirmayee Lenka ${ }^{1 *}$, G. C. Acharya ${ }^{2}$, P. Sahu ${ }^{4}$, D. K. Dash ${ }^{3}$, D. Samant ${ }^{2}$, \\ C. M. Panda ${ }^{3}$, K. N. Mishra ${ }^{3}$ and R. K. Panda ${ }^{3}$ \\ ${ }^{1}$ Department of Fruit Science, ICAR-Central Institute for Sub-tropical Horticulture, \\ Rehmankhera, P.O Kakori, Lucknow, Uttarpradesh-226 101, India \\ ${ }^{2}$ ICAR-Central Horticultural Experiment Station-IIHR, Bhubaneswar, Odisha, India \\ ${ }^{3}$ College of Agriculture, Odisha University of Agriculture and Technology, \\ Bhubaneswar, India \\ ${ }^{4}$ ICAR-Central Institute of Water Management, C.S Pur, Bhubaneswar, \\ Odisha -751 003, India
}

\section{A B S T R A C T}

\section{Keywords}

Psidium guajava, Plant growth regulator,

Micronutrient, Winter and rainy season

\section{Article Info}

Accepted:

04 September 2019

Available Online:

10 October 2019
The present investigation was undertaken at Central Horticultural Experiment StationICAR-IIHR, Bhubaneswar during two consecutive years 2017-18\& 2018-19. The experiments were laid out 2 Factorial Randomised Block Design with thirteen treatment and two season with three replications. The findings of the experiment revealed that the foliar application of various nutrients significantly increased the growth rate, flowering and fruiting characters of the plants over control. Maximum increase in plant growth in terms of plant height $(17.31 \%)$ and plant spread $(11.07 \%)$ were recorded in the plants receiving SA@100 ppm $\left(\mathrm{T}_{12}\right)$. Number of new emerging shoots was maximum (5.82 and 5.79) in Borax@0.6\% ( $\left.\mathrm{T}_{6}\right)$ which was found to be at par (5.73 and 5.78) with SA@100 ppm $\left(\mathrm{T}_{12}\right)$ in both rainy and winter crop, respectively. Maximum number of flowers per shoot (7.74), fruit set $(79.27 \%)$ and yield per plant $(24.43 \mathrm{~kg} / \mathrm{tree})$ were recorded under the treatments SA@100 ppm $\left(\mathrm{T}_{12}\right)$. Minimum days required for fruit set to maturity (130.00 and 131.00) were observed under the treatment $\mathrm{ZnSO}_{4} @ 0.6 \%\left(\mathrm{~T}_{3}\right)$ during rainy and winter seasons, respectively. The fruit retention was found maximum $(73.27 \%$ and 67.54 $\%)$ in NAA @ 100 ppm $\left(\mathrm{T}_{9}\right)$, which was at par with SA@100 ppm $\left(\mathrm{T}_{12}\right)$, while minimum (36.32\% and $34.94 \%)$ fruit retention was recorded in control for both rainy and winter season respectively. Application of NAA @ 100 ppm was also found to be equally good for fruit set and fruit retention during both the seasons of investigation.

\section{Introduction}

Guava (Psidium guajava L.) is one of the most important fruit crops of India. This fruit is considered as "poor man's apple" and "apple of tropics" because of its high nutritive value and low price in comparison to other fruit crops. It is often marketed as "super fruit" and 
considered a good source of riboflavin (30mg/100g) with seeds rich in omega-3, omega-6 polyunsaturated fatty acids and especially dietary fiber, as well as proteins, and mineral salts. Fruits are an excellent source of vitamin C (210-305 mg / $100 \mathrm{~g}$ fruit pulp). The pectin content in guava ranges between 0.5 to 1.8 per cent. It is a native of tropical America from where it was introduced in early $17^{\text {th }}$ century in India by Portuguese (Hayes, 1974).

Despite all favoring market opportunity and increasing importance of guava; both for table purposes and processing, it could not find much impetus in its cultivation due to low productivity and frequent crop failure. One of the reasons for low productivity is technology adoption by the growers. Production potential of any crop depends on the intrinsic potential of genotype and various phenological processes taking place within the plant. Application of the micronutrients and plant growth regulators are known to control or stimulate the physiological processes and also help in better expression of genetic potential under different environmental regimes by bringing about a change in nutrition and hormonalstatus of the plant.

The micro-nutrients play vital role in growth, flowering, retention and yield of fruits. The foliar feeding of micro-nutrients has gained much importance in recent years and comparatively more effective for rapid recovery of plants, as under high soil $\mathrm{pH}$ conditions, most of macro and micronutrients are unavailable. Various trials have been conducted on foliar feeding of micro-nutrients in different fruit crops and found effective in improving the vegetative growth, yield and quality of fruits (Sindhu et al., 1994; Banik et al., 1997 and Babu and Singh, 1998).Plant growth regulators like NAA and salicylic acid are known to play an essential role in plant growth, flower induction, fruit set, fruit growth, yield and quality. Work has been done to elucidate the significance of PGR to improve the quality and quantity of produce in many fruit crops (Hoda, 1986a; Tripathi and Shukla 2006; Amilkar et al., 2006; and Singh et al., 2007). Considering all the above facts and with a view to have better growth, flowering, fruiting and yield of fruits, a field experiment was carried out with the objective to study the effect of foliar application of micronutrients and growth regulators on growth, flowering and fruiting attributes of guava (Psidium guajava L.) cv. Allahabad Safeda.

\section{Materials and Methods}

The investigation was carried out during 20172019 at the research farm of Central Horticultural Experiment Station-ICAR-IIHR, Bhubaneswar. Eight years old plants of uniform size planted at $5 \times 5 \mathrm{~m}$ in square system were selected for the studies. The experimental site is located at $20^{\circ} 15^{\prime} \mathrm{N}$ latitude and $85^{\circ} 15^{\prime} \mathrm{E}$ longitude at an elevation of $25.5 \mathrm{~m}$ above mean sea level. Bhubaneswar falls under hot and humid tropical climate. The soil of the experimental site is sandy loam ( $80.45 \%$ sand, $10.19 \%$ silt and $9.36 \%$ clay) and strongly acidic $(\mathrm{pH} 4.6)$, low in organic carbon (0.20\%), N (189.8 kg ha), P (8.5 kg ha) and $\mathrm{K}(140.58 \mathrm{~kg}$ ha). Guava plants were spaced at $5 \mathrm{~m} \times 5 \mathrm{~m}$ accommodating 400 plants per ha. The experiment was laid out under Factorial Randomized Block Design with 13 treatments and two season (Rainy and Winter) with three replications.

This experiment was laid out in Factorial Randomized Block Design consisted thirteen treatments including $\mathrm{T}_{1}-$ Zinc Sulphate $0.2 \%$, $\mathrm{T}_{2}$ - Zinc Sulphate $0.2 \%, \mathrm{~T}_{3}$ - Zinc Sulphate $0.6 \%, \mathrm{~T}_{4}-$ Borax $0.2 \%, \mathrm{~T}_{5}-$ Borax $0.4 \%, \mathrm{~T}_{6}-$ Borax $0.6 \%, \mathrm{~T}_{7}$-NAA $50 \mathrm{ppm}, \mathrm{T}_{8}$-NAA 75 ppm, $\mathrm{T}_{9}$ - NAA $100 \mathrm{ppm}, \mathrm{T}_{10}$ - SA $50 \mathrm{ppm}$ $\mathrm{T}_{11^{-}} \mathrm{SA} 75 \mathrm{ppm} \mathrm{T}_{12^{-}} \mathrm{SA} 100 \mathrm{ppm} \mathrm{T}_{13^{-}}$ 
Control(Water Spray) and two season (Rainy and Winter). The treatments were applied three times before flowering, at 50\% fruit set and four weeks after fruit set during both the season. The observations on growth, flowering and fruiting parameters of guava plants were recorded as per standard procedures.

\section{Results and Discussion}

A perusal of the data presented in following tables clearly indicates that flowering and fruiting characteristics with growth parameters were significantly influenced with the foliar application of different micronutrients and bio-regulators.

The data presented in Table 1 clearly indicate that the effect of foliar application of different micronutrients and bio-regulators on growth parameters of guava cv. Allahabad Safeda was found significant. Per cent increase in plant height was recorded to be maximum ((21.94 and $12.68 \%$ ) in SA@100 ppm $\left(\mathrm{T}_{12}\right)$ which was found to be at par $(20.42,12.47)$ with SA@75 ppm $\left(\mathrm{T}_{11}\right)$ whereas minimum (14.79, $8.45)$ increase in tree height was recorded in control $\left(\mathrm{T}_{13}\right)$ during both rainy and winter season crop, respectively. Increase in plant spread was recorded to be maximum (11.07 $\%)$ under the treatment SA@) 100ppm ( $\left.\mathrm{T}_{12}\right)$, whereas it was at par (10.77 and $10.70 \%)$ with $\mathrm{ZnSO}_{4} @ 0.6 \%\left(\mathrm{~T}_{3}\right)$ and $\mathrm{ZnSO}_{4} @ 0.4 \%\left(\mathrm{~T}_{2}\right)$ and minimum $(8.10 \%)$ was observed in control $\left(\mathrm{T}_{13}\right)$. Maximum (5.82 and 5.79) number of new emerging shoots was recorded in Borax@0.6\% $\left(\mathrm{T}_{6}\right)$ which was found to be at par (5.73 and 5.78) with SA@100 ppm $\left(\mathrm{T}_{12}\right)$ in both rainy and winter crop, respectively. While, minimum (3.92 and 3.92) were recorded in control $\left(\mathrm{T}_{13}\right)$. The maximum $(30.88 \mathrm{~cm}$ and $17.73 \mathrm{~cm})$ length of bearing shoot was obtained with SA@100 ppm $\left(\mathrm{T}_{12}\right)$ followed by treatment Borax@0.6\% ( $\left.\mathrm{T}_{6}\right)$ and SA@75ppm $\left(\mathrm{T}_{11}\right)$ in both rainy and winter season crop, respectively, while minimum
(26.33 $\mathrm{cm}$ and $13.43 \mathrm{~cm}$ ) length of bearing shoot was observed in control $\left(\mathrm{T}_{13}\right)$.

Average shoot length on bearing shoot was recorded to be maximum $(30.88 \mathrm{~cm}$ and 17.73 $\mathrm{cm})$ under the treatment SA@100 ppm $\left(\mathrm{T}_{12}\right)$ While, minimum average shoot length (26.33 $\mathrm{cm}$ and $13.43 \mathrm{~cm}$ ) length on bearing shoot was recorded under control treatment.

The possible reason for increased vegetative growth of plant by application of salicylic acid might be because of salicylic acid imparting an important role in regulating a number of plant physiological processes including increase in cell metabolic rate and for the synthesis of auxin and/or cytokinin, Matwally et al., (2003). Bindhyachal et al., (2016) stated that foliar spray of salicylic acid $100 \mathrm{ppm}$ recorded maximum increase in vegetative growth parameters shoot length, number of leaves and leaf area over control. Similar results were reported by Kacha et al., (2012) in phalsa and Bisen et al., (2006) in sweet orange.

The vegetative growth of plant was also influenced by application of zinc and boron because zinc is required for the synthesis of tryptohan, which is a precursor of auxin that might have resulted in increased apical growth and thus increased height and spread.

The increment in plant height and stem girth with the foliar application of zinc, is in conformity with the findings of Kumar et al., 2015, Waskela et al., 2013.

Boron spray enhanced the vegetative growth, might be due to enforcement photosynthetic and other metabolic activities which lead to increase in various plant metabolites responsible for cell division and cell elongation, photosynthetic activity, respiration as well as growth of plant improved by boron Lal and Rao, (1954). The results are in 
conformity with Banik et al., (1997) in mango and Balakrishnan (2001) in guava (Table 2).

\section{Flowering and fruiting parameters}

\section{Number of flowers per shoot}

Data presented in Table 3 reveals that the number of flowers per shoot was significantly improved with the foliar application of different micronutrients and growth regulators. Maximum number of flowers per branch (7.74) was recorded with the foliar application of SA@100 ppm ( $\left.\mathrm{T}_{12}\right)$, which was significantly higher than all other treatments but statistically at par with Borax@0.4\% and SA@75 ppm (7.61 and 7.60), while the minimum (5.53) was recorded under control, during both year of experimentation.

Improvement in the number of flowers per branch as a result of foliar application of salicylic acid because it belongs to an extra ordinary diverse group of plant phenolic compound which induces flowering in plants (Raskin, 1992b). Foliar application of salicylic acid significantly increases the vegetative growth, fruit retention and yield and quality of guava (Bindhyachal et al., 2016). Boron application also enhanced the number of flowers per shoot, might be due to enforcement of photosynthetic and other metabolic activities which lead to increase in various plant metabolites responsible for cell division and cell elongation, photosynthetic activity, respiration as well as growth of plant improved by boron Lal and Rao (1954). The results are in conformity with Banik et al., (1997) in mango and Balakrishnan (2001) in guava

\section{Days required for fruit maturity}

The data regarding days taken for fruit maturity have been presented in Table 3. It is indicated that during rainy season, minimum number of days $(130.00,131.00$ days) were recorded with $\mathrm{ZnSO} 4 \mathrm{ZnSO}_{4} @ 0.6 \%\left(\mathrm{~T}_{3}\right)$, which was closely followed by the treatment ZnSO4@0.4percent, while maximum number of days (137.50 and 139.50) were recorded under control, during rainy and winter seasons, respectively.

The results are in accordance with the findings of Lal and Sen.,2002 who recorded the earliest fruit maturity (131.33 days) with foliar spray of $\mathrm{ZnSO} 4$ in guava cultivar Allahabad Safeda in a field experiment conducted in Rajasthan.

\section{Fruit set and Fruit retention}

The results of the present investigation revealed that influence of micronutrients and growth regulators on fruit set, and fruit retention.

It is clear from the results (Table 3) that maximum fruit setting (80.65 and $77.90 \%$ was recorded with plant received SA@100 ppm $\left(\mathrm{T}_{12}\right)$ and the fruit retention was found maximum $(73.27 \%$ and $67.54 \%)$ in NAA @ 100 ppm $\left(\mathrm{T}_{9}\right)$ which was at par with SA@100 ppm $\left(\mathrm{T}_{12}\right)$ in both rainy and winter season crop, respectively and minimum $(36.32 \%$ and $34.94 \%)$ fruit retention was recorded in control for both rainy and winter season respectively.

The present results revealed that NAA increase the fruit retention may be due to auxin is well known as inhibitors for abscissic acid and ethylene which cause fruit drop (Ram, 1983).

There is correlation between fruit drop and endogenous NAA status and existence of high level of internal auxin that prevent fruit drop. Since high level of endogenous hormones might help in building up endogenous hormone at appropriate level potent to enough reduces the fruit drop. 
Table.1 Effect of micronutrients and bio- regulators on tree growth character of guava

\begin{tabular}{|c|c|c|c|c|c|c|}
\hline \multirow[t]{2}{*}{ Treatments } & \multicolumn{2}{|c|}{$\begin{array}{c}\text { Increase in plant height } \\
(\%)\end{array}$} & \multirow[t]{2}{*}{ Mean } & \multicolumn{2}{|c|}{$\begin{array}{l}\text { Increase in plant } \\
\text { spread }(\%)\end{array}$} & \multirow[t]{2}{*}{ Mean } \\
\hline & Winter (S1) & Rainy (S2) & & $\begin{array}{l}\text { Winter } \\
\text { (S1) }\end{array}$ & Rainy (S2) & \\
\hline $\mathrm{T}_{1}-0.2 \% \mathrm{ZnSO}_{4}$ & 10.72 & 16.93 & 13.82 & 7.22 & 12.34 & 9.78 \\
\hline $\mathrm{T}_{2}-0.4 \% \mathrm{ZnSO}_{4}$ & 11.66 & 18.91 & 15.29 & 8.05 & 13.34 & 10.70 \\
\hline $\mathrm{T}_{3}-0.6 \% \mathrm{ZnSO}_{4}$ & 12.41 & 19.42 & 15.92 & 8.49 & 13.04 & 10.77 \\
\hline $\mathrm{T}_{4}-0.2 \%$ Borax & 10.73 & 17.20 & 13.97 & 7.20 & 13.15 & 10.18 \\
\hline$T_{5}-0.4 \%$ Borax & 11.23 & 18.33 & 14.78 & 7.48 & 12.36 & 9.92 \\
\hline$T_{6}-0.6 \%$ Borax & 11.29 & 18.83 & 15.06 & 7.82 & 13.01 & 10.41 \\
\hline $\mathbf{T}_{7}-50$ ppm NAA & 10.71 & 17.30 & 14.00 & 6.59 & 12.15 & 9.37 \\
\hline $\mathrm{T}_{8}-75 \mathrm{ppm}$ NAA & 10.97 & 17.53 & 14.25 & 7.26 & 12.61 & 9.94 \\
\hline$T_{9}-100$ ppm NAA & 11.73 & 17.96 & 14.84 & 7.51 & 12.59 & 10.05 \\
\hline $\mathrm{T}_{10}-50 \mathrm{ppm} \mathrm{SA}$ & 11.17 & 18.39 & 14.78 & 7.65 & 12.46 & 10.05 \\
\hline$T_{11}-75 p p m ~ S A$ & 12.47 & 20.42 & 16.44 & 7.90 & 12.56 & 10.23 \\
\hline$T_{12}-100$ ppm SA & 12.68 & 21.94 & 17.31 & 8.43 & 13.70 & 11.07 \\
\hline$T_{13}-($ Control $)$ & 8.45 & 14.79 & 11.62 & 5.17 & 11.02 & 8.10 \\
\hline Mean & 11.25 & 18.30 & & 7.44 & 12.64 & \\
\hline & $\mathbf{T}$ & $\mathbf{S}$ & TXS & $\mathbf{T}$ & $\mathbf{S}$ & TXS \\
\hline SE(d) & 0.639 & 0.250 & 0.903 & 0.380 & 0.149 & 0.538 \\
\hline CD (0.05) & 1.286 & 0.505 & NS & 0.766 & 0.300 & NS \\
\hline
\end{tabular}

Table.2 Effect of micronutrients and bio- regulators on number of new emerging shoot characters

\begin{tabular}{|c|c|c|c|c|c|c|}
\hline \multirow[t]{2}{*}{ Treatments } & \multicolumn{2}{|c|}{$\begin{array}{c}\text { Number of new } \\
\text { shoots/branch }\end{array}$} & \multirow[t]{2}{*}{ Mean } & \multicolumn{2}{|c|}{$\begin{array}{l}\text { Length of bearing shoot } \\
(\mathbf{c m})\end{array}$} & \multirow[t]{2}{*}{ Mean } \\
\hline & Winter (S1) & Rainy (S2) & & $\begin{array}{l}\text { Winter } \\
\text { (S1) }\end{array}$ & Rainy (S2) & \\
\hline $\mathrm{T}_{1}-0.2 \% \mathrm{ZnSO}_{4}$ & 4.77 & 4.78 & 4.78 & 15.62 & 26.80 & 21.21 \\
\hline $\mathrm{T}_{2}=0.4 \% \mathrm{ZnSO}_{4}$ & 4.51 & 4.48 & 4.50 & 16.11 & 27.30 & 21.70 \\
\hline $\mathrm{T}_{3}-\mathbf{0 . 6} \% \mathrm{ZnSO}_{4}$ & 5.37 & 5.33 & 5.35 & 16.68 & 27.71 & 22.20 \\
\hline$T_{4}-0.2 \%$ Borax & 5.13 & 5.05 & 5.09 & 15.91 & 26.53 & 21.22 \\
\hline $\mathrm{T}_{5}-\mathbf{0 . 4 \%}$ Borax & 5.26 & 5.33 & 5.30 & 16.77 & 27.64 & 22.21 \\
\hline $\mathrm{T}_{6}-0.6 \%$ Borax & 5.79 & 5.82 & 5.80 & 17.49 & 30.25 & 23.87 \\
\hline $\mathrm{T}_{7}-50$ ppm NAA & 4.36 & 4.33 & 4.35 & 15.88 & 26.67 & 21.28 \\
\hline $\mathrm{T}_{8}-75$ ppm NAA & 4.67 & 4.65 & 4.66 & 16.15 & 27.27 & 21.71 \\
\hline$T_{9}-100$ ppm NAA & 5.43 & 5.41 & 5.42 & 16.91 & 27.37 & 22.14 \\
\hline $\mathrm{T}_{10}-50 \mathrm{ppm} \mathrm{SA}$ & 5.12 & 5.14 & 5.13 & 16.53 & 27.83 & 22.18 \\
\hline$T_{11}-75 p p m ~ S A$ & 5.51 & 5.53 & 5.52 & 17.00 & 28.39 & 22.69 \\
\hline$T_{12}-100$ ppm SA & 5.78 & 5.73 & 5.76 & 17.73 & 30.88 & 24.31 \\
\hline$T_{13}-($ Control $)$ & 3.92 & 3.92 & 3.92 & 13.43 & 26.33 & 19.88 \\
\hline Mean & 5.05 & 5.04 & & 16.32 & 27.77 & \\
\hline & $\mathbf{T}$ & $\mathbf{S}$ & TX S & $\mathbf{T}$ & $\mathbf{S}$ & TXS \\
\hline SE(d) & 0.257 & 0.101 & 0.363 & 0.358 & 0.140 & 0.506 \\
\hline CD (0.05) & 0.517 & NS & NS & 0.721 & 0.283 & 1.020 \\
\hline
\end{tabular}


Table.3 Effect of micronutrients and bio- regulators on number of flowers per shoot and days to fruit maturity of guava

\begin{tabular}{|c|c|c|c|c|c|c|}
\hline \multirow[t]{2}{*}{ Treatments } & \multicolumn{2}{|c|}{ Number of flowers/shoot } & \multirow[t]{2}{*}{ Mean } & \multicolumn{2}{|c|}{ Days to fruit maturity } & \multirow[t]{2}{*}{ Mean } \\
\hline & Winter (S1) & Rainy (S2) & & $\begin{array}{c}\text { Winter } \\
\text { (S1) }\end{array}$ & Rainy (S2) & \\
\hline $\mathrm{T}_{1}-0.2 \% \mathrm{ZnSO}_{4}$ & 5.77 & 7.07 & 6.42 & 134.17 & 131.50 & 132.83 \\
\hline $\mathrm{T}_{2}-0.4 \% \mathrm{ZnSO}_{4}$ & 6.77 & 7.33 & 7.05 & 133.50 & 130.83 & 132.17 \\
\hline $\mathrm{T}_{3}-0.6 \% \mathrm{ZnSO}_{4}$ & 7.12 & 7.62 & 7.37 & 131.00 & 130.00 & 130.50 \\
\hline$T_{4}-0.2 \%$ Borax & 7.38 & 7.78 & 7.58 & 136.50 & 133.83 & 135.17 \\
\hline$T_{5}-0.4 \%$ Borax & 7.57 & 7.65 & 7.61 & 136.33 & 133.33 & 134.83 \\
\hline $\mathrm{T}_{6}-0.6 \%$ Borax & 7.63 & 5.83 & 6.73 & 135.83 & 132.83 & 134.33 \\
\hline $\mathrm{T}_{7}-50$ ppm NAA & 6.02 & 6.92 & 6.47 & 136.83 & 134.50 & 135.67 \\
\hline$T_{8}-75$ ppm NAA & 6.48 & 7.58 & 7.03 & 136.50 & 134.17 & 135.33 \\
\hline$T_{9}-100$ ppm NAA & 6.95 & 7.72 & 7.33 & 136.17 & 134.17 & 135.17 \\
\hline$T_{10}-50 \mathrm{ppm} \mathrm{SA}$ & 7.23 & 5.13 & 6.18 & 135.83 & 134.50 & 135.17 \\
\hline$T_{11}-75 p p m ~ S A$ & 7.50 & 7.70 & 7.60 & 135.50 & 134.17 & 134.83 \\
\hline$T_{12}-100$ ppm SA & 7.70 & 7.78 & 7.74 & 135.00 & 133.50 & 134.25 \\
\hline$T_{13}-($ Control $)$ & 6.17 & 4.90 & 5.53 & 139.50 & 137.50 & 138.50 \\
\hline Mean & 6.95 & 7.00 & & 135.59 & 133.45 & \\
\hline & $\mathbf{T}$ & $\mathbf{S}$ & TX S & $\mathbf{T}$ & $\mathbf{S}$ & TXS \\
\hline $\mathrm{SE}(d)$ & 0.122 & 0.048 & 0.173 & 0.719 & 0.282 & 1.017 \\
\hline CD (0.05) & 0.246 & NS & 0.348 & 1.449 & 0.568 & NS \\
\hline
\end{tabular}

Table.4 Effect of micronutrients and bio- regulators on fruit set and fruit retention of guava

\begin{tabular}{|c|c|c|c|c|c|c|}
\hline \multirow[t]{2}{*}{ Treatments } & \multicolumn{2}{|c|}{ Fruitset (\%) } & \multirow[t]{2}{*}{ Mean } & \multicolumn{2}{|c|}{ Fruit retention (\%) } & \multirow[t]{2}{*}{ Mean } \\
\hline & Winter (S1) & Rainy (S2) & & $\begin{array}{c}\text { Winter } \\
\text { (S1) }\end{array}$ & Rainy (S2) & \\
\hline $\mathrm{T}_{1}-0.2 \% \mathrm{ZnSO}_{4}$ & 61.69 & 71.24 & 66.47 & 48.64 & 53.69 & 51.16 \\
\hline $\mathrm{T}_{2}-0.4 \% \mathrm{ZnSO}_{4}$ & 66.90 & 72.49 & 69.69 & 50.33 & 54.94 & 52.63 \\
\hline $\mathrm{T}_{3}-0.6 \% \mathrm{ZnSO}_{4}$ & 69.56 & 73.77 & 71.67 & 56.03 & 57.51 & 56.77 \\
\hline$T_{4}-0.2 \%$ Borax & 73.39 & 73.46 & 73.43 & 58.30 & 59.05 & 58.67 \\
\hline$T_{5}-0.4 \%$ Borax & 73.94 & 75.00 & 74.47 & 62.34 & 63.15 & 62.74 \\
\hline$T_{6}-0.6 \%$ Borax & 74.60 & 75.16 & 74.88 & 63.44 & 65.25 & 64.34 \\
\hline $\mathbf{T}_{7}-\mathbf{5 0}$ ppm NAA & 68.45 & 69.48 & 68.97 & 64.27 & 62.24 & 63.25 \\
\hline $\mathrm{T}_{8}-75 \mathrm{ppm}$ NAA & 71.71 & 72.95 & 72.33 & 66.95 & 67.84 & 67.39 \\
\hline$T_{9}-100$ ppm NAA & 75.56 & 75.51 & 75.54 & 67.54 & 73.27 & 70.41 \\
\hline$T_{10}-50 \mathrm{ppm} \mathrm{SA}$ & 72.77 & 77.37 & 75.07 & 50.99 & 66.91 & 58.95 \\
\hline$T_{11}-75 p p m ~ S A$ & 75.58 & 78.16 & 76.87 & 56.24 & 68.40 & 62.32 \\
\hline$T_{12}-100$ ppm SA & 77.90 & 80.65 & 79.27 & 60.91 & 70.13 & 65.52 \\
\hline $\mathbf{T}_{13}$ - (Control) & 58.84 & 63.25 & 61.05 & 34.94 & 36.32 & 35.63 \\
\hline Mean & 70.84 & 73.73 & & 48.64 & 53.69 & \\
\hline & $\mathbf{T}$ & $\mathbf{S}$ & TXS & $\mathbf{T}$ & $\mathbf{S}$ & TXS \\
\hline SE(d) & 1.348 & 0.529 & 1.907 & 1.595 & 0.626 & 2.255 \\
\hline CD (0.05) & 2.716 & 1.065 & 3.841 & 3.213 & 1.260 & 4.544 \\
\hline
\end{tabular}


Table.5 Effect of micronutrients and bio-regulators on yield and yield attributing characters of guava

\begin{tabular}{|c|c|c|c|c|c|c|}
\hline \multirow[t]{2}{*}{ Treatments } & \multicolumn{2}{|c|}{ Fruit Yield (Kg/tree) } & \multirow[t]{2}{*}{ Mean } & \multicolumn{2}{|c|}{ Fruit Yield (t/ha) } & \multirow[t]{2}{*}{ Mean } \\
\hline & $\begin{array}{c}\text { Winter } \\
\text { (S1) }\end{array}$ & $\begin{array}{c}\text { Rainy } \\
\text { (S2) }\end{array}$ & & $\begin{array}{c}\text { Winter } \\
\text { (S1) }\end{array}$ & $\begin{array}{c}\text { Rainy } \\
\text { (S2) }\end{array}$ & \\
\hline $\mathrm{T}_{1}-0.2 \% \mathrm{ZnSO}_{4}$ & 8.23 & 14.65 & 11.44 & 3.29 & 5.86 & 4.58 \\
\hline $\mathrm{T}_{2}-0.4 \% \mathrm{ZnSO}_{4}$ & 8.97 & 17.07 & 13.02 & 3.59 & 6.83 & 5.21 \\
\hline $\mathrm{T}_{3}-0.6 \% \mathrm{ZnSO}_{4}$ & 9.91 & 18.81 & 14.36 & 3.96 & 7.52 & 5.74 \\
\hline $\mathrm{T}_{4}-0.2 \%$ Borax & 8.90 & 19.97 & 14.44 & 3.56 & 7.99 & 5.77 \\
\hline $\mathrm{T}_{5}-0.4 \%$ Borax & 10.65 & 21.00 & 15.83 & 4.26 & 8.40 & 6.33 \\
\hline$T_{6}-0.6 \%$ Borax & 11.35 & 23.60 & 17.48 & 4.54 & 9.44 & 6.99 \\
\hline$T_{7}-50$ ppm NAA & 8.17 & 14.39 & 11.28 & 3.27 & 5.75 & 4.51 \\
\hline$T_{8}-75$ ppm NAA & 9.06 & 16.33 & 12.70 & 3.62 & 6.53 & 5.08 \\
\hline$T_{9}-100$ ppm NAA & 9.88 & 17.70 & 13.79 & 3.95 & 7.08 & 5.52 \\
\hline$T_{10}-50$ ppm SA & 11.92 & 22.78 & 17.35 & 4.77 & 9.11 & 6.94 \\
\hline$T_{11}-75 p p m ~ S A$ & 13.70 & 26.48 & 20.09 & 5.48 & 10.59 & 8.04 \\
\hline$T_{12}-100$ ppm SA & 17.73 & 31.13 & 24.43 & 7.09 & 12.45 & 9.77 \\
\hline $\mathbf{T}_{13}-($ Control $)$ & 5.95 & 9.89 & 7.92 & 2.38 & 3.96 & 3.17 \\
\hline Mean & 10.34 & 19.52 & & 4.14 & 7.81 & \\
\hline
\end{tabular}

\begin{tabular}{|c|c|c|c|c|c|c|}
\hline & T & S & T X S & T & S & T X S \\
\hline SE(d) & 0.172 & 0.068 & 0.244 & - & - & - \\
\hline CD (0.05) & 0.347 & 0.136 & 0.491 & - & - & - \\
\hline
\end{tabular}

These results are in conformity with the findings of Yadav et al., (2011) in guava. Sharma and Tiwari (2015) stated that NAA reduce the fruit drop, improve the fruit set and fruit retention. Similar results were also obtained by Agnihotri et al., (2013) and Hada et al., (2013) (Table 4). By foliar sprays of SA fruit retention was increased might be due to better photosynthetic activity (Singh and Usha, 2003) leading to proper supply of carbohydrates to the fruits and also due to reduced abscission. Similar finding were also observed by Ahmed et al., (2015a); Ngullie et al., (2014) and Nicholas and Embree (2004).

\section{Yield}

The interaction effect of different treatments on season was found to be significant on fruit yield in both the year of experiment. The highest yield $(31.13 \mathrm{~kg} /$ tree and $17.73 \mathrm{~kg} / \mathrm{tree})$ was found in SA@100 ppm $\left(\mathrm{T}_{12}\right)$ treatment and lowest yield $(9.89 \mathrm{~kg} /$ tree and 5.95 $\mathrm{kg} /$ tree) was observed in control for both rainy and winter season, respectively (Table 5). Salicylic acid is responsible for increase the yield by increased the fruit set percentage, increase in fruit weight and number of fruits per tree. These findings are in agreement with the findings of Ahmed et al., (2015a); Faissal et al., (2014); Ngullie et al., (2014); Ashraf et al., (2012)

\section{References}

Agnihorti, A.; Tiwari, R. and Singh, O.P. 2013.Effect of crop regulators on growth yield and quality of guava. Annals .of plant and soil research 15(1): 56-57 
Ahmed, F. F.; Mansour, A. E. M. and Merwad, M. A. 2015a. Physiological studies on the effect of spraying salicylic acid on fruiting of Sukkary mango trees. Int. J. Chem. Tech. Res., 8(4): 2142-2149.

Amilkar, M.M., A.G. Luis, Dujarte V.M. Rosa, M. Consujelo, N. Vicente, G. Sergio, M. Nebauer, Perales and G. Jose-luis. 2006. Longterm effect of GA spray and Auxin application on crop value of "Clausellina" Satsuma. $J$. Amer. Soc. Hort. Sci., 13(5): 586-592.

Ashraf, M. Y.; Yaqub, M.; Akhter, J.; Khan, M. A.; Khan, A. and Ebert, G. 2013. Improvement in yield, quality and reduction in fruit drop in kinnow (Citrus reticulate Blanco) by exogenous application of plant growth regulators, potassium and zinc. Pakistan J. Bot., 45(SI): 433-440.

Babu N, AR Singh. 1998. Effect of Boron, Zinc and Copper sprays on growth and development of litchi fruits. Punjab, Hort. J.; 34(3-4):75-79.

Balakrishanan, K. 2001. Foliar spray of zinc, iron, boron and magnesium on vegetative growth, yield and quality of guava.Ann. Pl. Physiol.14(2):151-153.

Banik BC, Sen SK, Bose TK. 1997.Effect of zinc, iron and boron in combination with urea on growth, flowering, fruiting and quality of mango cv. Fazli. Environ. Eco- B.C.K.V., Kalyani., 15(1):122-125.

Banik, B.C.; Sen, S.K. and Bose, T.K. 1997. Effect of zinc, iron and boron in combination with urea on growth, flowering, fruiting and fruit quality of mango cv. Fazli. Environ. Ecol., 15 (1): 122-125.

Bindhyachal, R.; Mandal, B.Kr.; Kumar,U. Ravindra, K. and Kumar, P. 2016. Response of guava to boron and growth regulators spray. Asian J. Hort., 11(1): 146-150
Bisen, R.K.; Pandey, D.; Chaure, N.K.; Verma, S.; Shrivastava, D. and Agrawal, H.P. 2006. Drip irrigation scheduling, growth and yield of sweet orange. Environ. Ecol., 24(4): 714719 .

Faissal, F. A.; Mohamed K. K. and Hamdy I. M. I. 2014. The synergistic effects of using plant extracts and salicylic acid on yield and fruit quality of Keitte mango trees. Stem Cell, 5(2): 30-39.

Hada, T. S., Singh, B. K., Veer, K. and Singh, S. P.2013. Effect of different levels of boron and zinc on flowering, fruiting and growth parameter of winter season guava (Psidium guajava L.) cv. L49.The Asian J. Hort. 9(1): 53-56.

Hayes WB. 1974. Fruit Growing in India. Kitabistan, Allahabad.

Hoda, M.N. 1986a.Studies on the effect of ethrel, CCC and GA sprays on bearing of mango. Ph.D. Thesis R.A.U. (Bihar).

Kacha H.L, Viradia R.R, Leva H.M, Jat G., and Tank A.K. 2012. Effect of NAA, GA3 and ethrel on yield and quality of phalsa under South-Saurashtra condition. Asian J. Hort. 7(2):242-245.

Kumar, J., Kumar, R., Rai, R. and Mishra, D.S.2015. Response of 'Pant Prabhat' guava trees to foliar sprays of zinc, boron, calcium and potassium at different plant growth stages. The Bioscan, 10(2): 495-498

Lal, G. and Sen, N. L. 2002. Flowering and fruiting of guava (Psidium guajava L.) cv. Allahabad Safeda as influenced by application of nitrogen, zinc and manganese. Journal of EcoPhysiology, 5(3-4): 87-91.

Lal, K.N. and Rao, M.S. 1954. Micronutrient nutrition of plant. Bull, 166-75.BHU, Press Varanasi, India.

Matwally, A.I., Finkemeier, J.M., Georgi and K.J., Dietz.2003. Salicylic acid alleviates the cadmium toxicity in 
barly seedlings. Plant Physiology, 132: 272-81.

Ngullie, C. R.; Tank, T.V. and Bhanderi, D. R. 2014.Effect of salicylic acid and humic acid on flowering, fruiting, yield and quality of mango (Mangifera indica L.) cv. Kesar. Adv. Res. J. Crop Improvement, 5 (2): 136-139.

Nicholas, D. and C. Embree.2004. Blossom end fruitlet thinners affected affect crop load, fruit weight, seed number and return bloom of Northern Spy Apple. Hort. Sci. 39(6): 1309-1312.

Ram, S. 1983. Hormonal control of fruit growth and fruit drop in mango cv. Dashehari Acta Hort., 134: 169-178.

Sindhu PC, VP Ahlawat, AS Nain.1994.Effect of foliar spray of zinc sulphate on total soluble solids and acidity percentage of grapes cv. Perlette, Res. Bull, CCSHAU Hissar.

Singh, B. and Usha, K. 2003. Salicylic acid induced physiological and biochemical changes in wheat seedlings under water stress. Plant Growth Regul., 39(2): 137-141.

Singh, N.K., J. Prasad and H.K. Singh. 2007. Effect of micronutrients and PGRS on yield and physico-chemical characteristics of Aonla fruits in cv. NA-10.Ind. J. Hort., 64(2): 216-218.

Tripathi, V.K. and P.K. Shukla.2006.Effect of plant bioregulator on growth, yield and quality of strawberry cv. Chandar. $J$. Asian Hort., 2(4): 260-263.

Waskela, R.S., Kanpure, R.N., Kumawat, B.R. and Kachouli, B.K. 2013.Effect of foliar spray of micronutrients on growth, yield and quality of guava (Psidium guajava L.) cv. Dharidar. International Journal of Agricultural Sciences, 9(2): 551-556

Yadav, H.C.; Yadav, A. L.; Yadav, D.K. ; and Yadav P.K. 2011. Effect of foliar application of micronutrients and $\mathrm{GA}_{3}$ on fruit yield and quality of rainy season guava (Psidium guajava cv. L49.Plant Archives, 11(11): 147-149.

\section{How to cite this article:}

Jotirmayee Lenka, G. C. Acharya, P. Sahu, D. K. Dash, D. Samant, C. M. Panda, K. N. Mishra and Panda, R. K. 2019. Assess the Effect of Micronutrients and Bio-regulators on Growth, Flowering, Fruiting and Yield of Guava (Psidium guajava) cv. Allahabad Safeda. Int.J.Curr.Microbiol.App.Sci. 8(10): 401-409. doi: https://doi.org/10.20546/ijcmas.2019.810.042 